\title{
A Morphological Study of the Suprascapular Notch in a Sample of Scapulae at the University of Kwazulu Natal
}

\author{
Estudio Morfológico de la Escotadura Supraescapular en una \\ Muestra de Escápulas de la Universidad de KwaZulu-Natal
}

Manikum, C. ; Rennie, C.*; Naidu, E. C. S." \& Azu, O. O.*

MANIKUM, C.; RENNIE, C.; NAIDU, E. C. S. \& AZU, O. O. A morphological study of the suprascapular notch in a sample of scapulae at the University of KwaZulu Natal. Int. J. Morphol., 33(4):1365-1370, 2015.

SUMMARY: The suprascapular notch (SSN) is important, as it is a risk factor in the development of suprascapular nerve entrapment syndrome. The purpose of this study is to describe the morphology of the SSN of a sample of normal scapulae in the Discipline of Clinical Anatomy, University of KwaZulu Natal. Sixty scapulae were used consisting of 37 males and 23 females (mean age 51 years). The superior transverse diameter and maximal depth of the notches were measured. Comparisons were made of the notch in relation to the maximal width and length of the scapulae, laterality and sex. The Rengachary classification method was adopted to describe the shape of the SSN. Analysis of morphological variations showed Type II- wide blunted V-shaped notch to be predominant (65\%). Three scapulae had absent notches (Type I). The average notch depth and transverse diameter were $6.51 \pm 2.69 \mathrm{~mm}$ and $13.18 \pm 5.52$ $\mathrm{mm}$ respectively. The right $\mathrm{SSN}$ were significantly deeper than the left $(7.54 \pm 2.51 \mathrm{~mm})(\mathrm{p}<0.02)$. The male scapulae were distinctively larger, with females having a much shallower and wider notch. Understanding the morphological variation of the SSN is important when various radiological imaging techniques are utilized such as during arthroscopic shoulder operations and anaesthesia for landmarking of the suprascapular nerve.

KEY WORDS: Suprascapular notch; Morphology; Clinical anatomy; Nerve entrapment.

\section{INTRODUCTION}

Research has shown that approximately $20 \%$ (19.6\%) of South African volleyball players develop injuries that are shoulder related (Abdelnour, 2008). This is often due to suprascapular nerve entrapment (Polguj et al., 2013). The morphology of the suprascapular notch (SSN) (i.e. both shape and size) becomes essential, as it is the most likely site of compression or injury of the suprascapular nerve (Polguj et al., 2013). The suprascapular nerve is a branch from the upper trunk of the brachial plexus ( $\mathrm{C} 5$ and $\mathrm{C} 6$ ) and is found along the superior margin of the scapula, lying laterally and adjacent to the base of the coracoid process. The SSN is covered by the transverse scapular ligament, which converts the notch into a foramen transmitting the suprascapular nerve (Sangam et al., 2013).

Internationally, literature has shown that suprascapular nerve entrapment occurs in $1-2 \%$ of all patients that present with shoulder pain (Kannan et al., 2014), and this may be misdiagnosed (Polguj et al., 2013). In the athletes, there is an even higher risk of suprascapular nerve entrapment as it is associated with violent overhead movement (Polguj et al., 2011). Amongst volleyball players it has been reported to be as high as 33\% (Holzgraefe et al., 1994; Trojian et al., 2013) and 8-20\% of over-use injuries in high level English male volley ball players (Wang \& Cochrane, 2001).

In clinical practice, when utilizing radiological imaging such as ultrasound, MRI and CT during arthroscopic shoulder operation or suprascapular nerve blockade, it then becomes necessary to have an understanding of the morphological variation of the SSN (Yücesoy et al., 2009). This may increase success rates for these surgical procedures (Yücesoy et al.). Various methods such as radiological and clinical investigations, cadaveric and osteological studies have been proposed in the literature in order to classify the morphology of the SSN (Sinkeet et al., 2010; Iqbal \& Iqbal, 2011; Polguj et al., 2011; Jadhav,

\footnotetext{
School of Laboratory Medicine and Medical Sciences, Department of Clinical Anatomy, College of Health sciences, University of KwaZulu-Natal, Durban, South Africa.
} 
2012; Kannan et al.). The most widely used classification method by Rengachary et al. (1979). The Rengachary method classifies the SSN into six categories based on its shape: Type I, the whole superior margin of the scapula shows a wide depression from the medial superior angle to the base of the coracoid process; Type II, a wide and blunt $\mathrm{v}$-shaped notch; Type III, a symmetrical u-shaped notch; Type IV, a small, v-shaped notch; Type V, similar to Type III with the medial part of the ligament ossified and Type VI, with the ligament completely ossified forming a foramen. These studies presume that a small notch gave a greater chance of a nerve impingement than a large one (Kannan et al.). Furthermore, it has been hypothesized that suprascapular nerve entrapment is more likely to be associated with an arrow ' $V$ ' shaped notch. However, no direct correlation between notch type and suprascapular nerve entrapment has been shown clinically (Soni et al., 2012).

Numerous studies on Caucasian subjects especially in Europe and Asia have shown that the Type III (U-shape) notch was the most prevalent shape (Sinkeet et al.; Polguj et al., 2011; Iqbal \& Iqbal; Sangam et al.; Vasudha et al., 2013; Albino et al., 2013). In addition, only few studies have been conducted in the African population (viz Kenya and Nigeria) with no studies describing the morphology of the SSN within the South African population. More so, very little has been reported on the dimensions of the SSN in relation to age, gender or even the scapula dimensions in our environment.

Recent studies have modified Rengachary et al. classification, suggesting that relating the dimensions of the SSN to shape may yield a more precise catergorization (Polguj et al., 2013). A study by Yücesoy et al. illustrated through using ultrasound that the SSN depth was significantly higher in males than in females, and that there was no significant difference for the notch width between the two sexes. A similar study carried out by Polguj et al. (2013) reported that there is a positive correlation between morphological length of the scapula and maximum depth of the notch. Whilst Albino et al. concluded that gender, age and scapular dimensions are not related to the dimensions and type of suprascapular notch. Although these classification methods may seem to be more specific when compared with Rengachary's classification they are still quite new, and literature suggest that further investigations are warranted.

The aim of this study therefore, was to describe and compare the morphology and morphometry of the SSN within a South African population using normal dried osteological cadaveric scapulae comparing it to maximal width and length of the scapulae, laterality and sex.

\section{MATERIAL AND METHOD}

The study was conducted on the osteological collections in the Discipline of Clinical Anatomy, School of Laboratory Medicine and Medical Science, University of KwaZulu Natal at the Medical School Campus. Ethical approval was obtained from the UKZN Biomedical Research Ethics Committee (BREC) (Ethics number: BCA356/14). Of the total sample, of 200 scapulae, 30 right and 30 left dried cadaveric scapulae of known sex, age and race were selected. Within the sample, there were 4 sets of complete scapulae pairs. Scapulae that were broken and were of unknown age, sex and race were excluded from the study sample.

Morphometry. The method adopted by the study was by Kannan et al. The following measurements were taken using a digital calliper (0.01 mm resolution) (Refer to Figure 1):

I. The major longitudinal axis of the scapular body, which was measured from the medial angle of the scapula to the inferior angle of the scapula (A axis).

II. The major transversal axis scapular body, was taken from the lowest point of the glenoid cavity to the vertebral margin, at the level of the smooth surface over which the trapezius glides over the scapular (B axis).

III. The maximal depth of the suprascapular notch, which was measured as the maximal vertical distance from the superior margin of the notch to lowest point of the suprascapular notch.

IV. The maximal width of the suprascapular notch measured along the superior margin of the notch from medial to lateral at the points of inflexion.

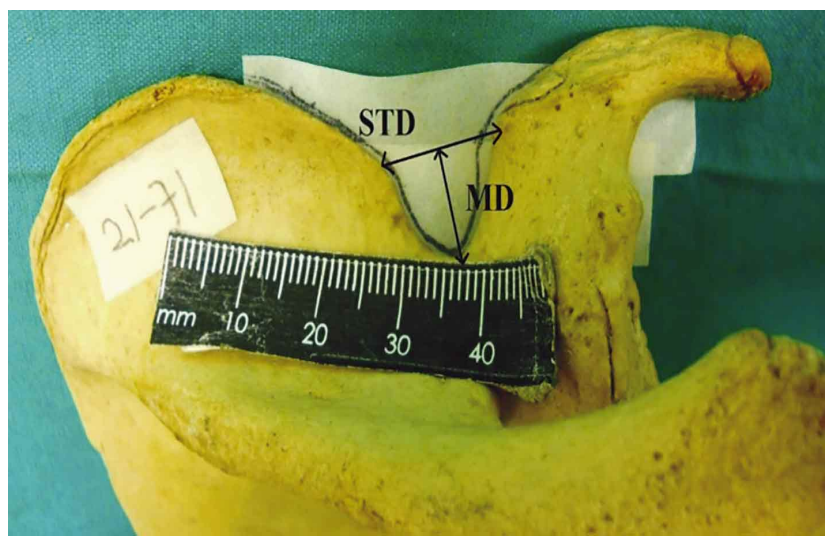

Fig. 1. Dimensions taken of the suprascapular notch. STD= superior transverse diameter, $\mathrm{MD}=$ maximal depth. 
Morphology. The shape of the suprascapular notch was classified using Rengachary's system. Recording were made off the replications of the notch on the lengths of tape.

Statistical Analysis. The data was analysed using the SPSS version 22.0 (SPSS Inc., Chicago Illinois, USA). Differences between the SSN measurements with sex, laterality and scapular dimensions were compared using the independent student t-test. Pearson's correlation was used to test the association between categorical variables (sex). A p-value of $<0.05$ was considered statistically significant.

\section{RESULTS}

Dimensions of the suprascapular notch. The sample consisted of 37 male and 23 female scapulae, aged from 12-81 years of age (mean age 51 years). The maximum depth
(MD) of the SSN ranged from a minimum of $0.00 \mathrm{~mm}$ (no notch present) to a maximum of $12.63 \mathrm{~mm}$. The mean notch depth was $6.51 \pm 2.69 \mathrm{~mm}$. The superior transverse diameter (STD) of the notch ranged from a minimum of $0.00 \mathrm{~mm}$ (no notch present) to a maximum of $27.01 \mathrm{~mm}$. The average superior transverse diameter was $13.18 \pm 5.52 \mathrm{~mm}$. The mean length and width of the scapula was $144.14 \pm 12.97 \mathrm{~mm}$ and $101.22 \pm 8.25 \mathrm{~mm}$ respectively.

Dimensions of the scapula in relation to the suprascapular notch. The dimensions of the scapular (i.e. length of scapular and width of scapular) were significantly larger in males. The width of the scapula was found to have no correlation between maximum depth or superior transverse diameter. The notch depth was larger in males, whilst the superior transverse diameter was wider in females. The depth of the SSN on the right side (mean: $7.54 \mathrm{~mm}$ ) was significantly deeper than the left (mean: $6.14 \mathrm{~mm}$ ) $\mathrm{p}<0.05$ (Tables I and II).

Table I. Parameters of scapulae in relation to sex.

\begin{tabular}{lcccc}
\hline Sex & $\begin{array}{c}\text { Scapula length } \\
\text { (Mean } \pm \text { SD) }\end{array}$ & $\begin{array}{c}\text { Scapular width } \\
(\text { Mean } \pm \text { SD) }\end{array}$ & $\begin{array}{c}\text { Notch MD } \\
(\text { Mean } \pm \text { SD) }\end{array}$ & $\begin{array}{c}\text { Notch STD } \\
(\text { Mean } \pm \text { SD) }\end{array}$ \\
\hline $\mathbf{M}$ & $149.70 \pm 11.65$ & $104.46 \pm 7.65$ & $6.99 \pm 2.52$ & $13.42 \pm 4.72$ \\
$\mathbf{F}$ & $135.18 \pm 9.64$ & $95.99 \pm 6.55$ & $6.62 \pm 1.87$ & $14.65 \pm 4.74$ \\
$\mathbf{P}$-value & $<\mathbf{0 . 0 0 1}$ & $<\mathbf{0 . 0 0 1}$ & 0.29 & 0.83 \\
\hline
\end{tabular}

$\mathrm{MD}=$ maximum depth, $\mathrm{STD}=$ superior transverse diameter.

Table II. Parameters of scapulae in relation to laterality.

\begin{tabular}{lcccc}
\hline Side & $\begin{array}{c}\text { Scapula length } \\
(\text { Mean } \pm \text { SD) }\end{array}$ & $\begin{array}{c}\text { Scapular width } \\
(\text { Mean } \pm \text { SD) }\end{array}$ & $\begin{array}{c}\text { Notch MD } \\
(\text { Mean } \pm \text { SD) }\end{array}$ & $\begin{array}{c}\text { Notch STD } \\
(\text { Mean } \pm \text { SD) }\end{array}$ \\
\hline Right & $142.94 \pm 12.62$ & $100.15 \pm 9.62$ & $7.54 \pm 2.51$ & $14.68 \pm 4.64$ \\
Left & $145.34 \pm 13.41$ & $102.28 \pm 6.62$ & $6.14 \pm 1.82$ & $13.03 \pm 4.75$ \\
P-value & 0.48 & 0.32 & $\mathbf{0 . 0 2}$ & 0.16 \\
\hline MD= maximum depth, STD $=$ superior transverse diameter. & &
\end{tabular}

$\square$ Type I ( complete absent of notch)
$\square$ Type III ( U shape)
$\square$ Type V ( U shape with partial ossification)

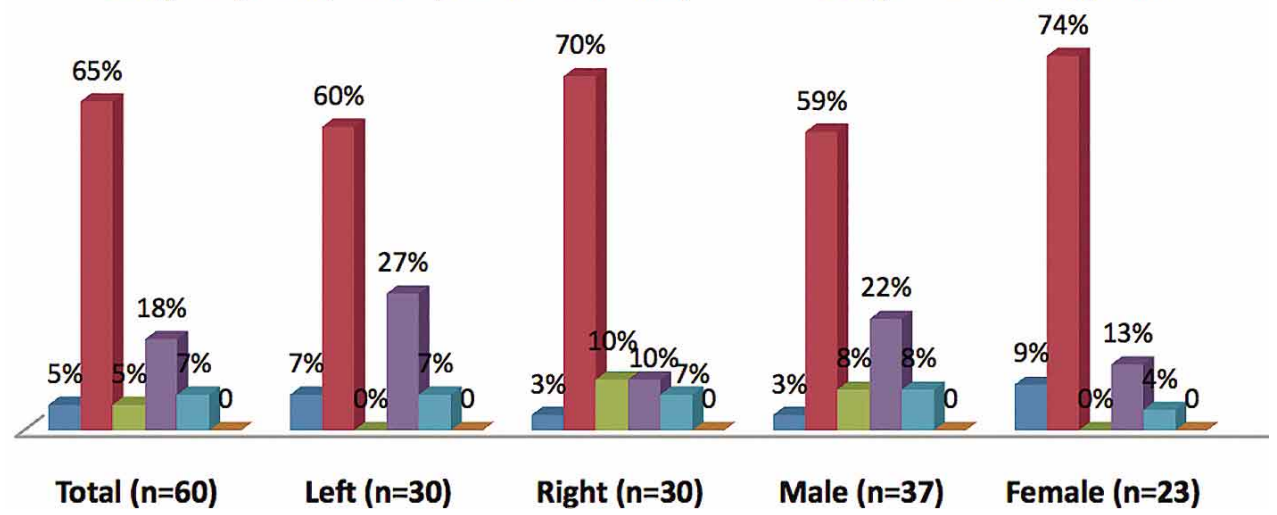

Fig. 2. Distribution of the types of suprascapular notches in sample in relation to side and sex. 


\section{Morphology of the suprascapular}

notch. In the present study 60 scapulae were catergorized according to Rengachary's system. Of these 60 scapulae, no scapulae were found to have completely ossified superior transverse scapular ligaments (Type VI). There were 3 scapulae found to have absent notches (Type I). On analysis of morphological variations of SSN, the following was found: Type I 5\%; Type II 65\%; Type III 5\%; Type IV 18\%; Type V $7 \%$ and Type VI $0 \%$. With regards to sex and laterality, the Type II (wide blunted V shape) was found to be predominant (Figs. 2 and 3).

\section{DISCUSSION}

The knowledge of SSN is of clinical importance in the adequate treatment and localization of suprascapular nerve entrapment. However, there is limited data on the morphology of the SSN in relation to gender, laterality or scapular dimensions within the South African population.

The Type II notch (wide blunted V shape) was found in $65 \%$ of the sample (superior transverse diameter was greater than the notch depth). This indicates that the chances of nerve impingement/ entrapment would be less. However the incidence of the Type III (U shaped notch in this study was 5\% whilst it was noted to be prominent in other studies; in the Kenyan population $29 \%$ (Sinkeet et al.), Indian population 35\% (Vandana \& Patil, 2013) and Polish population $56.16 \%$ (Polguj et al., 2011). Whilst Albino et al., noted that Type IV (V- shaped) notch was more prevalent in the Italian population (31.1\%). Odita et al. (1983)

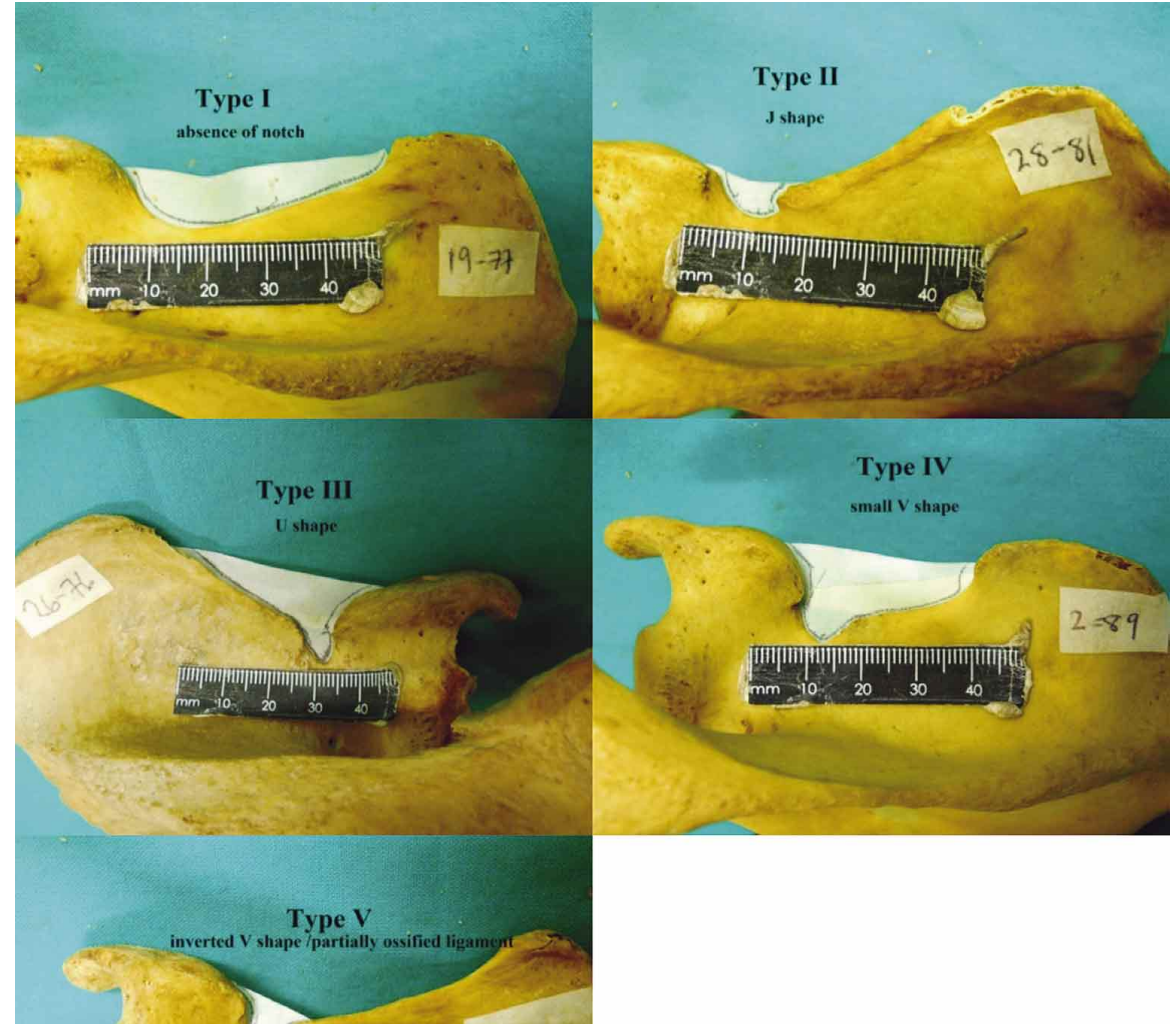

Fig. 3. Superior view of scapula showing the different notch types. indicated that the shape of the SSN is influenced by the ossification of coracoid process which occurred earlier in the Nigerian population compared to Caucasians, thereby explaining differences between populations and SSN morphology.

The incidence of complete ossification of the superior transverse scapular ligament (STSL) varies between different populations from 3.7 to $13.6 \%$ as shown in the literature (Polguj et al., 2011). Partial or complete ossification has been identified to be one of the predisposing factors in cases of suprascapular nerve entrapment (Soni et al.). The present study observed no cases with complete ossification of the STSL, with partial ossification of $6.7 \%$. In addition, $5 \%$ of the scapulae had complete absence of the SSN with a V shaped notch (Type IV) in 18.3\%. All these types may cause suprascapular nerve entrapment (Sinkeet et al.; Polguj et al., 2011; Soni et al.).

In this study, the dimensions of the SSN were compared between gender, sides and dimensions of the scapulae. Whilst the p-value obtained for all other dimensions in relation to sex and laterality were all found insignificant, the relation between the maximal depth of the notch and laterality proved to be significant (with a p- value of 0.023). This implies that the depth of the suprascapular notch was significantly related to the laterality of the scapula making the site for suprascapular nerve entrapment susceptible to this trend. 
The dimensions of the scapular (i.e. length of scapular and width of scapular) were significantly larger in males. The notch depth was larger in males, whilst the superior transverse diameter was wider in females. This finding is similar to an ultrasonographic study conducted by Yücesoy et al. but differs to Polguj et al. (2013) which noted that all dimensions are higher in males. Whilst, Albino et al. noted that gender did not influence the type of SSN morphology.

The study was performed with a limited number of dried cadaveric scapulae. Further research is needed to confirm the correlation between notch type and suprascapular nerve entrapment utilizing other sources such as radiographic images as well as a larger sample size.
CONCLUSION. The results of this study indicated that Type II notch (wide blunted V shape) was found to be the most prevalent type in comparison to previous studies. The study also found that the characteristics of the scapula (gender, age and dimensions) are related to the characteristics of the suprascapular notch (type and dimensions). Our findings demonstrated that there is a distinct difference between male and female scapula, reaffirming the difference in male and female size. A correlation between laterality and notch depth was found, with the depth of the right notch being significantly deeper. Results from this study show that research into this area of classification should be further investigated including a larger sample size for better external validity.

MANIKUM, C.; RENNIE, C.; NAIDU, E. C.S \& AZU, O. O. Estudio morfológico de la escotadura supraescapular en una muestra de escápulas de la Universidad de KwaZulu-Natal. Int. J. Morphol., 33(4):1365-1370, 2015.

RESUMEN: La incisura supraescapular (IS) es importante, ya que es un factor de riesgo en el desarrollo del síndrome de atrapamiento del nervio supraescapular. El propósito de este estudio fue describir la morfología de la IS de una muestra de escápulas normales en la disciplina de Anatomía Clínica de la Universidad de KwaZulu-Natal. Se utilizaron sesenta escápulas, 37 de hombres y 23 de mujeres (edad media 51 años). Se midieron el diámetro transversal superior y la profundidad máxima de las incisuras. Se realizaron comparaciones de la incisura en relación al ancho máximo y la longitud de la escápula, su lateralidad y el sexo. Se utilizó el método de clasificación de Rengachary para describir la forma de la IS. El análisis de las variaciones morfológicas mostró que el Tipo II, muesca amplia roma en forma de V, fue predominante (65\%). Tres escápulas no presentaron incisuras (Tipo I). La Media de la profundidad y diámetro transversal fueron $6,51 \pm 2,69 \mathrm{~mm}$ y $13,18 \pm 5,52 \mathrm{~mm}$, respectivamente. Las IS derechas fueron significativamente más profundas que las izquierdas $(7,54 \pm 2,51 \mathrm{~mm})(\mathrm{p}<0,02)$. Las escápulas de los hombres fueron significativamente de mayor tamaño que las de mujeres, con una incisura más superficial y ancha. La comprensión de las variaciones morfológicas de la IS son relevantes ya que diversas técnicas de imágenes radiológicas son utilizadas durante cirugías artroscópicas y anestesia del hombro para estimar puntos anatómicos del nervio supraescapular.

PALABRAS CLAVE: Incisura supraescapular; Morfología; Anatomía clínica; Atrapamiento nervioso.

\section{REFERENCES}

Abdelnour, H. Prevalence and pattern of injuries among players at the university of the Western Cape volleyball club. MSc. Thesis. Cape Town, University of the Western Cape, 2008. Available from: http://hdl.handle.net/11394/ 3167

Albino, P.; Carbone, S.; Candela, V.; Arceri, V.; Vestri, A. R. \& Gumina, S. Morphometry of the suprascapular notch: correlation with scapular dimensions and clinical relevance. BMC Musculoskeletal Disord., 14:172, 2013.

Holzgraefe, M.; Kukowski, B. \& Eggert, S. Prevalence of latent and manifest suprascapular neuropathy in high-performance volleyball players. Br. J. Sports Med., 28(3):177-9, 1994.

Iqbal, K. \& Iqbal. R. Classification of suprascapular notch according to anatomical measurements in human scapula. J. Coll. Physicians Surg. Pak., 21(3):169-70, 2011.
Jadhav, S. D. The suprascapular notch: Its various shapes in Indian dry scapula. Res. J. Pharm. Biol. Chem. Sci., 3(4):1085-90, 2012.

Kannan, K.; Kannan, N. S.; Anbalagan. J. \& Rao, S. Morphometric study of suprascapular notch in Indian dry scapula with specific reference to the incidence of completely ossified superior transverse scapular ligament. J. Clin. Diagn. Res., 8(3):7-10, 2014.

Odita, J. C.; Ugbodaga, V. I.; Omene, J. A. \& Okolo, A. A. Humeral head and coracoid ossification in Nigerian newborn infants. Pediatr. Radiol., 13(5):276-8, 1983.

Polguj, M.; Sibinski, M.; Grzegorzewski, A.; Grzelak, P.; Majos, A. \& Topol, M. Variation in morphology of suprascapular notch as a factor of suprascapular nerve entrapment. Int. Orthop., 37(11):2185-92, 2013. 
Polguj, M.; Jedrzejewski, K. S.; Podgórski, M. \& Topol, M. Correlation between morphometry of the suprascapular notch and anthropometric measurements of the scapula. Folia Morphol. (Warsz), 70(2):109-15, 2011.

Rengachary, S. S.; Neff, J. P.; Singer, P. A. \& Brackett, C. E. Suprascapular entrapment neuropathy: a clinical, anatomical, and comparative study. Part 1: clinical study. Neurosurgery, 5(4):441-6, 1979.

Sangam, M. R.; Sarada Devi, S. S.; Krupadanam, K. \& Anasuya, K. A study on the morphology of the suprascapular notch and its distance from the glenoid cavity. J. Clin. Diagn. Res., 7(2):189-92, 2013.

Sinkeet, S. R.; Awori, K. O.; Odula, P. O.; Ogeng'o, J. A. \& Mwachaka, P. M. The suprascapular notch: its morphology and distance from the glenoid cavity in a Kenyan population. Folia Morphol. (Warsz), 69(4):241-5, 2010.

Soni, V.; Malik, L.; Shukla, S.; Chabbra, N. G. \& Gaur, N. Morphometric analysis of the suprascapular notch. Internet $J$. Biol. Anthropol., 5(1):1-5, 2012.

Trojian, H.; Hall, M. L. \& Aerni, G. Suprascapular Neuropathy. Medscape, 2015. Available from: http:// emedicine.medscape.com/article/92672-overview

Vandana, R. \& Patil, S. Morphometric study of suprascapular notch. Natl. J. Clin. Anat., 2(3):140-4, 2013.

Vasudha, T. K.; Ashwija Shetty, Sadashivana Gowd \& Rajasekhar, S. S. S. N. Morphological study on suprascapular notch and superior transverse scapular ligaments in human scapula. Int. J. Med. Res. Health Sci., 2(4):793-8, 2013.

Wang, H. K. \& Cochrane, T. Mobility impairment, muscle imbalance, muscle weakness, scapular asymmetry and shoulder injury in elite volleyball athletes. J. Sports Med. Phys. Fitness, 41(3):403-10, 2001.

Yücesoy, C.; Akkaya, T.; Ozel, O.; Cömert, A.; Tüccar, E.; Bedirli, N.; Unlü, E.; Hekimoglu, B. \& Gümüs, H. Ultrasonographic evaluation and morphometric measurements of the suprascapular notch. Surg. Radiol. Anat., 31(6):409-14, 2009.
Correspondence to:

Dr. Onyemaechi O. Azu

School of Laboratory Medicine and Medical Sciences

Department of Clinical Anatomy

Nelson R. Mandela School of Medicine

College of Health sciences

University of KwaZulu-Natal

Private Bag X54001

Durban

4000

SOUTH AFRICA

Email: azu@ukzn.ac.za

Received: 19-01-2015

Accepted: 03-09-2015 